\title{
IN SEARCH OF RETENTION: VOLUNTEERS IN A BRAZILIAN NGO
}

\author{
Submission: 29/11/2016 \\ Accept: $12 / 08 / 2018$ \\ Marcos Aurelio Gomes de Aquino ${ }^{1}$ \\ Carlos Eduardo Cavalcante ${ }^{2}$ \\ Patrícia Trindade Caldas ${ }^{3}$ \\ Josiete da Silva Mendes ${ }^{4}$
}

\begin{abstract}
This study aims to analyse the motives that lead current and prospective volunteers to engage in volunteer activity at the Cidade Viva Foundation in the city of João Pessoa, state of Paraíba, Brazil. To that end, the model proposed by Cavalcante (2016) is employed to describe volunteers' motivational profiles at different points in time: their prior expectations, at the moment when they join the organization, and when they quit. The methodology chosen includes descriptive research and analysis of data collected through questionnaire-based interviews with volunteers at the Cidade Viva Foundation using inferential statistics (Student's $t$ test and Bonferroni test -ANOVA). Among the most significant findings is the predominance of the altruistic profile, followed by the social justice profile, the learning profile, the affiliation profile, and the selfish profile, both in prior expectations and at the moment of joining. Similarly, the selfish profile was least common.
\end{abstract}

Keywords: Third sector; volunteer work; motivation in volunteer work; turnover in volunteer work.

1 Master of Administration from University of Paraíba. Faculdade Paraibana, FAP. João Pessoa, Paraíba, Brazil. E-mail:adm.marcos@bol.com.br. ORCID: https://orcid.org/0000-0003-2931-7872

2 Doctor of Administration from University of Rio Grande do Norte. Universidade Federal da Paraíba. João Pessoa, Paraíba, Brazil.

Email: cavalcanteeduardo@gmail.com. ORCID:https://orcid.org/0000-0003-1861-0459

3 Master of Production Engineering from University of Paraíba. Universidade Federal de Campina Grande. Campina Grande, Paraíba, Brazil.

Email: ptcaldas@yahoo.com.br. ORCID:https://orcid.org/0000-0002-3495-596X

4 Master of Administration from University of Paraíba. Universidade de Pernambuco. Recife, Pernambuco, Brazil.

Email: josiete5@hotmail.com. ORCID: https://orcid.org/0000-0002-9766-3761

Rev. AdM. UFSM, SANTA MARIA, V. 13, NÚMERo 1, P. 144-164, 2020 


\section{RESUMO}

O presente estudo busca analisar as motivações que levam os atuais e os pretensos voluntários a engajarem-se na atividade voluntária da Fundação Cidade Viva na cidade de João Pessoa-PB. Para tanto, é utilizado o modelo proposto por Cavalcante (2016) que permite traçar o perfil motivacional dos voluntários em momentos distintos, tanto para a expectativa, entrada e evasão dos voluntários. Metodologicamente, optou-se por uma pesquisa descritiva e coleta de dados por meio da aplicação de questionário com voluntários da Fundação Cidade Viva utilizando estatísticas inferenciais (teste $t$ de Student e testes de Bonferroni - ANOVA).Quanto aos resultados mais significativos, verifica-se predominância do perfil altruístas, seguido do perfil justiça social, aprendizagem, afiliação, e o perfil egoísta tanto no modelo de expectativas quando no de entrada. Semelhantemente, o perfil egoísta foi o menos aceito.

Palavras-chave: Terceiro Setor; Trabalho voluntário; Motivação no trabalho voluntário; Rotatividade no trabalho voluntário.

\section{INTRODUCTION}

The term "third sector" arose to designate social and economic activity that falls under the aegis of neither the first sector (the State) nor the second sector (the market). With the distinction among these terms, the work of non-governmental organizations (NGOs) and not-forprofit organizations is said to belong to the third sector (FERNANDES, 1994; COELHO, 2000).

According to Smith (1991), the term "third sector" was first used in the United States in the mid-1970s to designate the social sector in which not-for-profit organizations and NGOs produce and distribute public goods and services . It arose primarily as a result of the crisis of the welfare state, whose attempts to guarantee public benefits and services to the population proved incapable of solving all existing social problems. Thus, the third sector attempts to fill the gaps left by the first (public) and the second (private) sectors, which are no longer able to effectively respond to social demands, especially with respect to the State (COSTA, 2002; RODRIGUES, 1997; SALAMON, 1994; FERREIRA, 2008).

Volunteer work in the third sector has become essential to this sector's viability. Volunteer work is undertaken spontaneously by altruistic individuals who seek to benefit society rather than themselves, as described by Cavalcante et al. (2001), who claim that volunteer work arises from an idea of sacrificing one's own self-interests to benefit and contribute to the collective good. This work does not replace the role of government but rather complements it. Volunteer work is performed by citizens who donate their time and use their skills freely for the purpose of making a difference in society and benefitting other people, a group, or an organization. This subject merits study because of its importance to social work (CVSP, 2001; BARELI; LIMA 2012).

According to Azevedo (2007), Cavalcante (2016), and Trigueiro (2010), volunteers typically dedicate approximately four hours per week to volunteer work, whereas full-time employees work 40 hours per week. Despite the shorter time contributed, volunteer work is a fundamental part of the activity of third sector organizations.

One important point to bear in mind is that volunteers bring a wide range of expectations to their work. Only the volunteer knows his or her true motivation in undertaking volunteer work. Thus, the individual becomes a key part of the organization, which should make an effort to retain the volunteer. For this reason, institutions must invest in their human resources if they want to achieve a high quality of work and social impact and avoid high turnover rates (COSTA, 2002).

Teodósio (2001) claims that the high rate of volunteer turnover experienced by many NGOs results from the dissipation of volunteers' initially high levels of commitment over the 
course of their work. Assis, Viegas, and Ckagnazaroff (2012) agree that high turnover hinders the effectiveness of the organization's work in that individuals quit just as they are gaining a good understanding of their job. Their departure entails various costs, including a decline in productivity and severance procedures, in addition to the costs of recruiting, interviewing, and training a replacement, which disrupts the functioning, culture, and organizational interaction of the group and directly affects the quality of service offered.

Therefore, it is important to understand a volunteer's motivational profile to comprehend, manage, and maintain it. In his study on the subject, Calvalcante (2016) proposes a model that traces several possible profiles for volunteers - altruism, social justice, affiliation, learning, and selfishness - to identify volunteers' motivations at different points in time, focusing on volunteers' prior expectations, the moment when they join, and the moment when they quit.

Based on this model, the present study aims to analyse the motives that lead current and would-be volunteers to engage in volunteer work at the Cidade Viva Foundation, located in the city of João Pessoa, state of Paraíba, Brazil. To that end, the study presents volunteer candidates' expectations for their volunteer experience, lists volunteers' reasons for beginning work, and cites volunteers' most common reasons for quitting. It should be noted that this study is part of a research project conducted by the

The Cidade Viva Foundation was chosen as a case study because it is an institution that works with volunteer activities, organizing approximately 350 volunteers, a number that periodically swells to 700 during specific events. The location lends itself to research because of the significant number of volunteers. The foundation itself recognizes the need for a study that elucidates the factors that motivate volunteers to join, stay, and possibly leave and thus contributes to a better understanding of turnover among members. The institution has ties to the First Baptist Church of Bessamar Evangelical Association, formed for the purpose of not only preaching Christian values but also engaging with issues that affect humanity such as hunger, drug use, and poverty, among others, seeking to change society.

In terms of methodology, a descriptive study using a quantitative approach was chosen. The data were gathered through questionnaire-based interviews with volunteers at the institution under study; the data were then analysed using descriptive and inferential statistics (mean; standard deviation; coefficient of variation; percentage; comparisons with the Bonferroni test; Student's $t$ test for independent samples, and analysis of variance (ANOVA)).

In addition to this introduction, this article presents a theoretical framework for the third sector and volunteer work, followed by an exposition of the theoretical model proposed by Cavalcante(2016) that is used in this study. Next, the methodological procedures are described, followed by the presentation and analysis of the results and final considerations.

\section{THEORETICAL FRAMEWORK}

\subsection{THIRD SECTOR}

Despite the popularity of the general term "third sector," little is known about it. The term is normally associated with NGOs, charitable or religious works, and the service sector of the economy. Linked to the lack of knowledge about the term is a scarcity of studies on the topic in Brazil, in addition to little mention of its origins (ALVES, 2002).

According to the Third Sector Guide (2005) and Smith (1991), the term "third sector" arose in the United States in the mid-1970s. It should be noted that differences in the terms used by different cultures - charitable sector, independent sector, voluntary sector, NGOs, social economy, and philanthropy, among others - create difficulties for studies of similarities among the au- 
thors in each country (DIMAGGIO et.al., 1990; SALAMON; ANHEIER, 1992cited by ALVES, 2002).

In Brazil, the term "third sector" has been used since the early 1990 s to designate notfor-profit civil society organizations created and maintained primarily by volunteers to address social problems (SOUR, 1999; AZEVEDO, 2008).

As time passed and the concept of the third sector and its characteristics developed, it came to be associated with a variety of organizational forms: professional associations, social welfare organizations, religious organizations, and foundations (RIBEIRO, 2010). Third sector entities resemble private companies in their structural organization and resemble public entities in their missions (FERNANDES, 1994). This phenomenon assumes the existence of a first sector, consisting of the State as constituted by the public administration (government) aimed at serving the public, and a second sector, organized by the market, individuals, and companies that seek profit by producing and marketing goods and services to meet the needs of society (RIBEIRO, 2010).

As noted above, it must be said that the third sector differs from the others in that its activities rely on the work of volunteers.

\subsection{VOLUNTEER WORK}

The subject of volunteer work is important due to its prevalence in the social field, in which it emerged in the early $20^{\text {th }}$ century in Brazil in response to the need to support and aid the poorest (CVSP, 2001). It is an activity that arises from the idea of renouncing self-interests in favour of the interests, wellbeing, and development of other people and the collective good (CAVALCANTE et al., 2011).

In Brazil, and in Latin America generally, volunteer work has been closely associated with the Catholic church, which is characterized by its acts of Christian charity. According to Amorim and Amatuzzi (2011), the principles of faith and love for one's neighbour make religion a field that is ripe for the development of volunteer work in that charitable giving, good acts, and participation in volunteer activities are part of religious belief, which in turn plays an important role in the development of volunteerism.

Despite the marked informality that is found in the third sector, volunteer activities in Brazil are legally regulated by Law 9.608/08 (BRASIL, 1998). Article 1 of this law defines volunteer work as unremunerated service that is rendered by an individual to any type of public entity or to a private not-for-profit institution for civic, cultural, educational, scientific, recreational, or social assistance purposes, including mutual assistance. This law underscores that, regardless of what motivation drew the person to the service, in keeping with its voluntary nature, the work must be performed of the person's own free will, without pay, by a single individual for a not-for-profit organization for the public good.

One point that warrants emphasis is the relationship that is established between the individual and the work performed, which in the third sector may involve both volunteers and formal employees. There are notable differences between volunteers and employees, including their work schedules: on average, a volunteer works between four and six hours per week, whereas on average, a formal employee works 40 hours per week on the job. It should be noted that because volunteer work requires less time commitment, the volunteer may participate in several NGOs simultaneously (MEDEIROS, 2013; CAVALCANTE, 2016).

Similar to any other type of organization, third sector entities also experience management problems that are often specific to the nature of the services and the work provided. Assis et al. (2012), Costa (2002), and Kummer et al. (2014) agree that some of the third sector's 
management problems are due to managing a workforce in which high turnover rates result in higher costs to the organization. According to Chapman and White (2012) and Ress, Moraes,and Nakano (2010), these costs are related to the recruitment, selection, training, and severance of a new volunteer until he or she is able to fully perform the assigned job. Costa $(2002$, p. 55) explains it thus: "turnover represents a very high cost to the institution, especially when it entails a significant amount of job training. It takes a combination of strategies to achieve ideal results."

A study of individuals' expectations and motivations for volunteer work, as well as their reasons for quitting, can help address the problem of high turnover rates in these organizations by identifying points to guide management's efforts to motivate volunteers to remain and develop within the organization. Cavalcante's work (2016) addresses this issue.

\subsection{CAVALCANTE'STHEORETICAL MODEL (2016)}

Cavalcante's theoretical model (2016) seeks to identify the expectations and motivations that lead individuals to join, remain in, and quit volunteer activity, sketching a motivational profile based on the following: (1) the volunteer's expectations at the moment of joining, before beginning work; (2) the volunteer's instrumentalist decision about which NGO to join to satisfy these initial expectations; (3) the volunteer's stay in the volunteer activity, drawing on expectancy theory to show whether initial aspirations or new motivations keep the volunteers engaged with the organization; and (4) the moment of departure, to understand the motives that lead volunteers to quit.

With regard to the first three moments (expectations, joining, and staying), volunteers can be classified according to the following five factors: altruism, social justice, affiliation, learning and self-interest.

According to Cavalcante (2016), the "altruism" factor refers to a subjectively perceived sense of self-sacrifice that drives the volunteer to face risky, unhealthy, or dangerous working conditions and is marked by a social conscience and universalist character. The "social justice" factor refers to a sense of equality, citizenship, and social justice that leads the volunteer to act locally to restore citizenship by aiding people and communities in precarious situations. The "affiliation" factor refers to volunteers who seek a sense of belonging and friendship by contributing to society. The "learning" factor is not primarily concerned with issues of pressing need or suffering but rather with a desire to better one's own and others' condition simultaneously, combining personal development with social improvement. The fifth factor, "self-interest," is related to the ego, status, privileges, and protection; this volunteer engages in self-promotion among the individuals or communities served. Box 1 shows the five factors and their indicators as they are expressed at the moments of "expectations" and "joining."

Box 1-Indicators of the motivational factors of altruism, social justice, affiliation, learning, and selfishness

\begin{tabular}{|c|c|c|}
\hline \multirow{2}{*}{ Factors } & \multicolumn{2}{|c|}{ Moment } \\
\cline { 2 - 3 } Altruism & $\begin{array}{c}\text { Expectations } \\
\text { Help others; }\end{array}$ & $\begin{array}{c}\text { Jivining people a better chance in life; } \\
\text { Do something that matters. }\end{array}$ \\
\hline Social justice & $\begin{array}{c}\text { Reduce social injustice; } \\
\text { Be a useful member of my community. }\end{array}$ & $\begin{array}{c}\text { Help out my community; } \\
\text { Improve the quality of life in the community }\end{array}$ \\
\hline Affiliation & $\begin{array}{c}\text { Meet people with the same interests; } \\
\text { Make new friends. }\end{array}$ & $\begin{array}{c}\text { Make new friends; } \\
\text { Have something to do with my free time. }\end{array}$ \\
\hline Learning & $\begin{array}{c}\text { Seek out new challenges; } \\
\text { Gain new knowledge and skills. }\end{array}$ & $\begin{array}{c}\text { Seek out new challenges; } \\
\text { Learn something. }\end{array}$ \\
\hline $\begin{array}{c}\text { Self-interes- } \\
\text { ted }\end{array}$ & $\begin{array}{c}\text { To feel like a better person; } \\
\text { To boost my self-esteem. }\end{array}$ & $\begin{array}{c}\text { For recognition; } \\
\text { To feel like a better person. }\end{array}$ \\
\hline
\end{tabular}

Source: Adapted from Cavalcante (2016). 
It may be observed that the profiles are ranked along a scale, with the highest being altruism and the lowest being self-interest, thus attributing characteristics to the various profiles of the research subjects (MEDEIROS, 2013).

The motives for quitting were grouped into the following three factors: religious motives, personal motives, and scarcity of resources. This model was adopted for the purposes of the present study. Details on the methodological procedures that were used follow.

\section{METHODOLOGICAL PROCEDURES}

This work can be classified as a descriptive case study of the Cidade Viva Foundation, located in João Pessoa, Paraíba. This foundation has links to the First Baptist Church of Bessamar Evangelical Association and grew out of the church's need to move beyond simply preaching Christian values to address practical issues that affect humanity such as hunger, drug use, and poverty, among others, with the goal of transforming society.

The study universe consisted of approximately 350 volunteers at the Cidade Viva Foundation who share in common their unremunerated work in the institution. Two samples were taken from among those who completed the questionnaire: one sample contained 250 would-be volunteers and the other 65 current volunteers at the Cidade Viva Foundation. The two sample groups differ in their profiles in that the first group contains individuals who would like to engage in volunteer work whereas the second contains individuals who already have at least one year of experience working in one of the foundation's seven groups/ministries. The sample groups were chosen by the non-probability sampling technique based on the meetings that were scheduled during the data collection period.

The application of questionnaires was chosen as a data collection technique to gather a large amount of data in a manner that fosters free expression through anonymity and uniformity in the assessment of the data (GIL, 1999; MARCONI; LAKATOS, 2010, 2011).

The data were analysed quantitatively, using a spreadsheet to organize the data, and through descriptive and inferential statistical techniques and resources (mean; standard deviation; coefficient of variation; percentage; comparisons using the Bonferroni test; Student's $t$ test for independent samples, and ANOVA).This description of how the study was conducted is followed by the presentation and analysis of the data.

\section{PRESENTATION AND ANALYSIS OF THE RESULTS 4.1 EXPECTATIONS OF WOULD-BEVOLUNTEERS}

The sociodemographic profile of the respondents shows that the mean age was $36,68 \%$ were women, $42.8 \%$ were married, $40.8 \%$ were single, $57.6 \%$ had higher education, $64 \%$ were professionals, and the mean monthly income was $R \$ 6,377.00$ (but could vary from $R \$ 500.00$ to $R \$ 30,000.00$ ).

A majority said that family members (47.3\%) or friends (70.1\%) engage or had engaged in volunteer work, and $58.4 \%$ participate in other volunteer work; however, $90.9 \%$ consider their volunteer work at the foundation to be important. Most of the respondents (72.4\%) said that they had made a personal choice to participate in volunteer work, with $42.9 \%$ citing religious motives and $26.9 \%$ a desire to help others. These motivations are in line with the intrinsic Christian values proposed by the Cidade Viva Foundation.

The motivations that were cited by candidates for volunteer work at the Cidade Viva Foundation ranged from the altruistic to selfish profiles. 
Table 1-Motivations of would-be volunteers

\begin{tabular}{cccc}
\hline Profile & Overall mean & Standard deviation & Coefficient of variation \\
Altruism & 9.15 & 1.63 & $17.86 \%$ \\
Social justice & 8.73 & 1.92 & $21.96 \%$ \\
Affiliation & 7.64 & 2.59 & $33.92 \%$ \\
Learning & 8.32 & 2.26 & $27.15 \%$ \\
Self-interest & 4.91 & 3.39 & $68.98 \%$ \\
\hline
\end{tabular}

Source: Research data

The data in Table 1 show that would-be volunteers identified most strongly with the altruistic motivation (mean higher than 9.15), with low data dispersion. Social justice also played a leading role, averaging 8.73 with a low standard deviation. It was found that this profile matches what the Cidade Viva Foundation advocates in its charter: "promoting and restoring human dignity, contributing in relevant areas of society" (CIDADE VIVA, 2014).

The "affiliation" and "learning" profiles, however, showed a considerable dispersion in respondents" answers. Finally, the "self-interest" profile had the lowest mean in the sample, indicating that individuals had little interest in engaging in volunteer work for merely self-serving reasons. In this sense, all of the results are consistent with the work of Moura and Souza (2008), Cavalcante et al. (2011), Mascarenhas et al. (2013), and Cavalcante (2016) and reinforce the finding by Clary, Snyder and Ridge (1992) that the motivations of would-be volunteers for engaging in volunteer work are influenced by altruism.

The sociodemographic profiles and the motivations of would-be volunteers at the $\mathrm{Ci}$ dade Viva Foundation were analysed to discover whether motivation is correlated with age, level of education, or income.

Table 02 shows that the analysis found nine weak negative correlations between age and motivation during the expectations phase, of which two were highly significant.

Table 2 - Expectations phase - Correlations between age and motivation

\begin{tabular}{|c|c|c|c|}
\hline \multicolumn{2}{|c|}{ Sociodemographic profile } & \multirow{2}{*}{ Motivation } & \multirow{2}{*}{ Correlation } \\
\hline Age & & & \\
\hline Pearson Correlation & $-.161^{*}$ & \multirow{3}{*}{ Help others (Altruism - 01) } & \multirow{3}{*}{1} \\
\hline Sig. (2-tailed) & .012 & & \\
\hline $\mathrm{N}$ & 244 & & \\
\hline Pearson Correlation & $-.154^{*}$ & \multirow{3}{*}{$\begin{array}{l}\text { Make a difference in people's lives (Altruism - } \\
02 \text { ) }\end{array}$} & \multirow{3}{*}{2} \\
\hline Sig. (2-tailed) & .017 & & \\
\hline $\mathrm{N}$ & 242 & & \\
\hline Pearson Correlation & $-.163^{*}$ & \multirow{3}{*}{$\begin{array}{l}\text { Give people a better chance in life (Altruism - } \\
04 \text { ) }\end{array}$} & \multirow{3}{*}{3} \\
\hline Sig. (2-tailed) & .011 & & \\
\hline $\mathrm{N}$ & 243 & & \\
\hline Pearson Correlation & $-.165^{*}$ & \multirow{3}{*}{$\begin{array}{c}\text { Contribute to the betterment of society (Social } \\
\text { Justice - 04) }\end{array}$} & \multirow{3}{*}{4} \\
\hline Sig. (2-tailed) & .010 & & \\
\hline $\mathrm{N}$ & 242 & & \\
\hline Pearson Correlation & $-.151^{*}$ & \multirow{3}{*}{ Learn to work with people (Learning - 01) } & \multirow{3}{*}{5} \\
\hline Sig. (2-tailed) & .019 & & \\
\hline $\mathrm{N}$ & 243 & & \\
\hline Pearson Correlation & $-.161^{*}$ & \multirow{3}{*}{ Acquire new knowledge/skills (Learning - 02) } & \multirow{3}{*}{6} \\
\hline Sig. (2-tailed) & .011 & & \\
\hline $\mathrm{N}$ & 245 & & \\
\hline
\end{tabular}




\begin{tabular}{|c|c|c|c|}
\hline Pearson Correlation & $-.141 *$ & \multirow{3}{*}{ Seek new challenges (Learning - 03) } & \multirow{3}{*}{7} \\
\hline Sig. (2-tailed) & .028 & & \\
\hline $\mathrm{N}$ & 242 & & \\
\hline Pearson Correlation & $-.220(* *)$ & \multirow{3}{*}{ Learn something new (Learning - 04) } & \multirow{3}{*}{8} \\
\hline Sig. (2-tailed) & .001 & & \\
\hline $\mathrm{N}$ & 240 & & \\
\hline Pearson Correlation & $-.193(* *)$ & \multirow{3}{*}{ Feel important (Selfish- 05) } & \multirow{3}{*}{9} \\
\hline Sig. (2-tailed) & .002 & & \\
\hline $\mathrm{N}$ & 245 & & \\
\hline
\end{tabular}

Source: Research data (2014).

Table 2 shows that all correlations are negative and weak, with the exception of the eighth and ninth, associated with the "learning" and "self-interest" profiles, respectively, which are highly significant.

The first, second, and third correlations (related to "Altruism - 01, 02, and 04,", respectively) indicate that younger would-be volunteers were more likely to view themselves as helping others, changing people's lives, or giving people a better chance in life.

The fourth correlation, which is associated with the "social justice" profile, is also inversely proportional, indicating that younger respondents were more likely to view themselves as contributing to the betterment of society.

With regard to correlations 5, 6, 7, and 8, which are related to the profile "Learning-01, 02,03 , and $04, "$, respectively, it can be noted that the younger the would-be volunteer was, the more likely he or she was to cite learning to work with people, acquiring new knowledge/skills, seeking new challenges, and learning something new as reasons for participating in the foundation's volunteer work. The eighth correlation stands out as being more significant. Although the others are no less important, the eighth motivation is significant to the foundation because it could serve as an effective point for recruiting volunteers, given that volunteers are more apt to engage in this activity in search of new knowledge.

Finally, correlation 9, which belongs to the "selfish- 05" profile, stands out as significant, showing that younger individuals are driven to engage in volunteer work by a desire to feel important.

An analysis of the correlations between level of education and motivations in the expectations phase revealed five correlations, of which two were weakly positive, including one of high significance. The remaining three were weak negative correlations, as shown by Table 3 below:

Table 3- Expectations phase - Correlations between level of education and motivation

\begin{tabular}{|c|c|c|c|}
\hline \multicolumn{2}{|c|}{$\begin{array}{c}\text { Sociodemographic profile } \\
\text { Level of education }\end{array}$} & Motivation & Correlation \\
\hline $\begin{array}{c}\text { Pearson Correlation } \\
\text { Sig. (2-tailed) } \\
\mathrm{N}\end{array}$ & $\begin{array}{c}225\left(^{* *}\right) \\
.000 \\
249\end{array}$ & $\begin{array}{l}\text { To be a useful member of my community (So- } \\
\text { cial justice - } 03 \text { ) }\end{array}$ & 1 \\
\hline $\begin{array}{c}\text { Pearson Correlation } \\
\text { Sig. (2-tailed) } \\
N\end{array}$ & $\begin{array}{l}.155^{*} \\
.015 \\
247\end{array}$ & $\begin{array}{c}\text { Contribute to the betterment of society (Social } \\
\text { justice - 04) }\end{array}$ & 2 \\
\hline $\begin{array}{l}\text { Pearson Correlation } \\
\text { Sig. (2-tailed) } \\
\text { N }\end{array}$ & $\begin{array}{c}-.141^{*} \\
.029 \\
241 \\
\end{array}$ & For recognition (Selfish-01) & 3 \\
\hline $\begin{array}{c}\text { Pearson Correlation } \\
\text { Sig. (2-tailed) } \\
\mathrm{N}\end{array}$ & $\begin{array}{c}-.155^{*} \\
.015 \\
247 \\
\end{array}$ & $\begin{array}{l}\text { Have something to do with my free time(Sel- } \\
\text { fish-02) }\end{array}$ & 4 \\
\hline $\begin{array}{c}\text { Pearson Correlation } \\
\text { Sig. (2-tailed) } \\
\text { N }\end{array}$ & $\begin{array}{c}-139 * \\
.028 \\
250 \\
\end{array}$ & Learn to work with people (Selfish- 05) & 5 \\
\hline
\end{tabular}

Source: Research data (2014). 
The first and second correlations in Table 03 show that, as their educational levels rise, volunteer candidates are more likely to express a desire to be useful members of their community and to make a contribution to improving society. Although the correlations are weak, correlation 1 is significant, which may show indications of a possible causal relationship between level of education and the motivation "to be a useful member of my community." Correlations 3 , 4 , and 5 show that as the level of would-be volunteers' education declines, they are more likely to describe their motivations for volunteering at the foundation as a way to achieve recognition, make use of their free time, and learn to work with people, respectively.

The analysis of correlations between income and motivation during the expectations phase showed only a single weak negative correlation of low significance (Table 4).

Table 4- Expectations phase - Correlations between income and motivation

\begin{tabular}{|c|c|c|c|}
\hline \multicolumn{2}{|c|}{$\begin{array}{l}\text { Sociodemographic profile } \\
\text { Income }\end{array}$} & Motivation & Correlation \\
\hline Pearson Correlation & $-.147^{*}$ & \multirow{3}{*}{$\begin{array}{l}\text { Have something to do with my free ti- } \\
\text { me(Selfish-02) }\end{array}$} & \multirow{3}{*}{1} \\
\hline Sig. (2-tailed) & .021 & & \\
\hline $\mathrm{N}$ & 247 & & \\
\hline
\end{tabular}

Source: Research data (2014).

The data in the table above show a weak negative correlation with the "self-interested" profile. This correlation signifies that, as would-be volunteers' income level declines, they are more likely to cite a desire to have something to do with their free time as a reason for volunteering.

Several conclusions were reached based on the results of the correlations observed between the sociodemographic data and motives for volunteering during the "expectations" phase. First, the correlations between age and motivation are similar to the findings of studies such as those by Matsuda (2002) and Silva and Villela (2008), who observe that the lower the age of would-be volunteers, the greater their motivation to participate in this activity.

Second, the correlations between educational level and motivation to volunteer reinforce the findings by Sevignani (2007) and Bang and Ross (2009), who report the highest rates of volunteer involvement among college graduates.

Finally, with regard to the correlations between income and motivation, Silva and Villela (2008) also conclude that individuals with a lower income are more inclined to engage in volunteer work.

With regard to the significant differences among groups in the questions that comprise the sociodemographic part of the questionnaire applied during the "expectations" phase, the use of ANOVA and Bonferroni and Student's $t$ tests made it possible to identify four differences among groups that are linked to level of education, having a family member who engaged in volunteer work, occupation, and participation in some other volunteer work.

Table 5-Differences among groups - Level of education - Altruism

\begin{tabular}{|c|c|}
\hline \multirow{2}{*}{ Level of education } & $\begin{array}{c}\text { Altruism 1 } \\
\text { "Expectations" variable } \\
\text { Mean for variables of Altruistic Motivation - 1 (Help others) }\end{array}$ \\
\hline \multirow{3}{*}{$\begin{array}{c}\text { "Some primary school" } \\
\text { Mean = 5.33 }\end{array}$} & "Completed primary school": Group mean = 10.00 \\
\cline { 2 - 2 } & "Some secondary school": Group mean = 9.90 \\
\cline { 2 - 2 } & "Completed secondary school": Group mean = 9.67 \\
\cline { 2 - 2 } & "Some higher education": Group mean = 9.86 \\
\cline { 2 - 2 } & "College graduate": Group mean = 9.39 \\
\cline { 2 - 2 } & "Post-graduate study": Group mean = 9.43 \\
\hline
\end{tabular}

ReV. AdM. UFSM, SANTA MARIA, V. 13, NÚMERO 1, P. 144-164, 2020 


\begin{tabular}{|c|c|c|}
\hline \multicolumn{3}{|r|}{$\begin{array}{c}\text { Altruism } 2 \\
\text { "Expectations" variable }\end{array}$} \\
\hline \multicolumn{2}{|l|}{ Level of education } & $\begin{array}{l}\text { Mean for variables of Altruistic Motivation - } 2 \text { (Change people's } \\
\text { lives) }\end{array}$ \\
\hline $\begin{array}{l}\text { "Some primary school" } \\
\text { Mean }=5.67\end{array}$ & $\mathbf{x}$ & "College graduate": Group mean = 9.39 \\
\hline & & Altruism 3 \\
\hline Level of education & & $\begin{array}{c}\text { Mean for variables of Altruistic Motivation - } 3 \text { (Bring hope to the } \\
\text { less fortunate) }\end{array}$ \\
\hline \multirow{6}{*}{$\begin{array}{c}\text { "Some primary school" } \\
\text { Mean }=5.00\end{array}$} & \multirow{6}{*}{$\mathbf{x}$} & "Completed primary school": Group mean = 9.67 \\
\hline & & "Some secondary school": Group mean = 9.50 \\
\hline & & "Completed secondary school": Group mean = 9.50 \\
\hline & & "Some higher education": Group mean = 9.61 \\
\hline & & "College graduate": Group mean = 9.47 \\
\hline & & "Post-graduate study": Group mean = 9.26 \\
\hline
\end{tabular}

Table 5 shows that "educational level" revealed differences in all cases in which "some primary school" was analysed in relation to "Altruism1, 2, and 3." In this case, the results show that "some primary school" scored lower means in comparison to all other variables and motivations. It is inferred from this result that candidates for volunteer positions at the foundation who did not complete primary school have less altruistic motivations than other candidates, given that their lower mean scores indicate that their motives do not reflect a concern for helping their fellow human beings.

The finding by Caldana et al.(2012) that more highly educated groups stand out as being more altruistic than their less educated counterparts may help explain the data gathered at the Cidade Viva Foundation.

A second difference is identified with regard to respondents' occupation between those who identified themselves as "pensioners" and "students" on the variables of "Altruism - 2" and "Selfish- 5," as shown in Table 6.

Table 6 - Differences among groups - Occupation

\begin{tabular}{|c|c|c|c|}
\hline \multicolumn{4}{|c|}{ "Expectations" variable } \\
\hline \multicolumn{3}{|c|}{ Differences among groups with regard to occupation } & Motivation \\
\hline $\begin{array}{l}\text { "Pensioner" } \\
\text { Mean = } 7.36\end{array}$ & $\mathbf{X}$ & $\begin{array}{c}\text { "Student" } \\
\text { Mean }=9.48\end{array}$ & $\begin{array}{c}\text { Altruistic - } 2 \\
\text { "To change peoples' lives" }\end{array}$ \\
\hline $\begin{array}{l}\text { "Pensioner" } \\
\text { Mean = } 2.79\end{array}$ & $\mathbf{x}$ & $\begin{array}{c}\text { "Student" } \\
\text { Mean = } 5.90\end{array}$ & $\begin{array}{c}\text { Selfish- 5 } \\
\text { "To feel important" }\end{array}$ \\
\hline
\end{tabular}

Source: Research data (2014).

The data in Table 6 show that on average, the "student" variable scored higher than the "pensioner" variable. In the case of the former, it is inferred that student candidates for volunteer work at the foundation are more likely to perceive volunteering as a way to make a difference in people's lives and are more inclined to altruistic motivations. In contrast, pensioners' lower scores are interpreted as meaning that pensioners are less likely to view volunteering as a way to make a difference in people's lives and are less motivated by altruism. The findings by Moraes et al. (2014) corroborate these results.

In the case of the latter, the correlations between the "student" and "pensioner" occupations and the selfish motivational profile, it can be inferred that would-be volunteers also view 
volunteer work as a way to feel important, though this tendency was stronger among students than among pensioners. These results are in line with the findings by de Oliveira et al. (2010), who portray students who apply for volunteer positions as having "self-interested" motivations, with a quest for leadership positions ranking as one of their primary motivations.

\subsection{VOLUNTEERS' REASONS FOR JOINING VOLUNTEER ACTIVITIES}

The "joining" factor seeks to explain the reasons that led volunteers who work at the Cidade Viva Foundation to join. The difference between this factor and the "expectations" factor lies in the fact that the "joining" factor focuses on the responses of individuals who have already been active for up to one year in the foundation's volunteer work whereas the "expectations" factor focuses on would-be volunteers' expectations prior to beginning volunteer work.

The sociodemographic profile of active volunteers at the Cidade Viva Foundation shows that on average, they are approximately 37 years of age, predominantly women (61\%), 53\% married, $40 \%$ single, and very well educated (with $57 \%$ having higher education); $74 \%$ are employed, with $n$ mean monthly household income of $R \$ 5,986.52$ (ranging from $R \$ 1,300.00$ to $R \$ 22,000.00$ ).

The majority reported having a family member $(53 \%)$ or friends $(80 \%)$ who had engaged in volunteer work; $65 \%$ had already worked as volunteers, though $18 \%$ volunteered with a different institution. When asked whether they had been invited by someone to volunteer, $47 \%$ of the respondents said that an invitation to participate had been decisive in their choice. In addition, $70 \%$ reported that they had another reason for volunteering that was not among the choices offered. Religious reasons (62.79\%) and a desire to help others (20.93\%) were the most commonly cited motivations.

Table 7 shows the data concerning the reasons for joining that were collected from volunteers who were already active in the Cidade Viva Foundation.

Table 7 - Moment of joining: Would-be volunteers' motivations

\begin{tabular}{cccc}
\hline Profile & Overall mean & Standard deviation & Coefficient of variation \\
Altruism & 8.06 & 2.73 & 33.91 \\
Social justice & 6.92 & 2.93 & 42.34 \\
Affiliation & 6.12 & 3.21 & 52.49 \\
Learning & 6.40 & 3.18 & 49.64 \\
Self-interested & 3.41 & 3.26 & 95.62 \\
\hline
\end{tabular}

Source: Research data

The altruism profile stands out again among the data in Table 7, with the highest mean value (8.06), and the high values for the standard deviation and coefficient of variation render the sample heterogeneous, with a wide variation in the responses obtained. These data indicate that the respondents did not consistently cite only one motivation for undertaking volunteer work at the foundation studied.

Table 07 also shows that the social justice, affiliation, and learning profiles obtained average values, ranking slightly below the altruism profile but nevertheless being well represented. A gradual increase in the standard deviation and high coefficients of variance is also observed, indicating dispersion among the responses.

Finally, the selfish profile obtained a low mean value (3.41) but high standard deviation (3.26) and coefficient of variation (92.62\%), characterizing the sample as disperse and heterogeneous. It may be inferred that these volunteers are not driven by status, self-promotion, privileges, or prestige but rather by a desire to combat social inequality and help the needy. 
The results obtained from both the "joining" phase and the "expectations" phase are consistent with Cavalcante's model (2016) and with the studies by Boz and Palaz (2007)and de Burns et al. (2006), indicating that the highest mean in the study is at the "altruism" level. The prominence of altruism as a motive is also because the study was conducted in an institution with a religious character, given that McCurley and Lynch (1998) classify altruism as a religious conviction. Moreover, given the religious nature of the foundation studied, selfishness is the motive that was least cited as a reason for engaging in this activity.

For the analysis of correlations between the sociodemographic data and motivation at the time of "joining," the results refer to the correlation of age with motivation and educational level with motivation because there are no other correlations.

Three weak positive correlations are observed between age and motivation at the time when volunteers joined the Cidade Viva Foundation, as shown in Table 8.

Table 8-Moment of joining- Correlations between age and motivation

\begin{tabular}{|c|c|c|c|}
\hline $\begin{array}{c}\text { Sociodemographi } \\
\text { Age }\end{array}$ & & Motivation & Correlation \\
\hline Pearson Correlation & $.287^{*}$ & \multirow{3}{*}{ Do something important (Altruism - 05) } & \multirow{3}{*}{1} \\
\hline Sig. (2-tailed) & .023 & & \\
\hline $\mathrm{N}$ & 63 & & \\
\hline Pearson Correlation & $.270^{*}$ & \multirow{3}{*}{ Acquire new knowledge/skills (Learning - 02) } & \multirow{3}{*}{2} \\
\hline Sig. (2-tailed) & .036 & & \\
\hline $\mathrm{N}$ & 61 & & \\
\hline Pearson Correlation & $.258^{*}$ & \multirow{3}{*}{ Seek new challenges (Learning - 03) } & \multirow{3}{*}{3} \\
\hline Sig. (2-tailed) & .043 & & \\
\hline $\mathrm{N}$ & 62 & & \\
\hline
\end{tabular}

Source: Research data (2014).

The first correlation shown in Table 8 is a weak positive correlation that belongs to the "altruism profile -5 ". Volunteers are more likely to express a desire to do something important as their age increases. Similarly, as volunteers' age increases, they are more likely to cite one of the reasons associated with the "learning profile -2 and 3 ": a desire to acquire new knowledge and skills or to seek new challenges.

An inversion in the relationship between age and altruism was observed between the "expectations" phase and the "joining" phase: although a younger age is associated with higher motivations related to altruism and learning during the expectations phase, the inverse is true when active volunteers describe their motivation at the moment of joining.

Corroborating the results shown in Table 8, a study by Ferreira et al. (2012) shows that altruism and learning are increasingly cited as motives as the volunteers' age increased. In this context, in may be inferred that the older the volunteer, the greater his or her intention to forego personal needs is because, according to Clary, Snyder, and Ridge (1992), altruism is associated with a desire to help others more than oneself, to feel compassion for people in need, and to feel that it is important to help others.

With regard to the correlations between level of education and motivation at the moment of joining, six correlations were observed, of which four were weak positive, one was weak negative, and one was moderate negative. 
Table 9-Moment of joining - Correlations between level of education and motivation

\begin{tabular}{|c|c|c|c|}
\hline $\begin{array}{l}\text { Sociodemograpl } \\
\text { Level of edu }\end{array}$ & file & Motivation & Correlation \\
\hline Pearson Correlation & $.252 *$ & \multirow{3}{*}{ Help others (Altruism. - 01) } & \multirow{3}{*}{1} \\
\hline Sig. (2-tailed) & .048 & & \\
\hline $\mathrm{N}$ & 62 & & \\
\hline Pearson Correlation & $.251^{*}$ & \multirow{3}{*}{$\begin{array}{l}\text { Make a difference in people's lives (Al- } \\
\text { truism - 02) }\end{array}$} & \multirow{3}{*}{2} \\
\hline Sig. (2-tailed) & .049 & & \\
\hline $\mathrm{N}$ & 62 & & \\
\hline Pearson Correlation & $.278^{*}$ & \multirow{3}{*}{$\begin{array}{l}\text { Bring hope to the less fortunate (Al- } \\
\text { truism }-03 \text { ) }\end{array}$} & \multirow{3}{*}{3} \\
\hline Sig. (2-tailed) & .029 & & \\
\hline $\mathrm{N}$ & 62 & & \\
\hline Pearson Correlation & $.270 *$ & \multirow{3}{*}{ Do something important (Altruism - 05) } & \multirow{3}{*}{4} \\
\hline Sig. (2-tailed) & .033 & & \\
\hline $\mathrm{N}$ & 63 & & \\
\hline Pearson Correlation & $-.297^{*}$ & \multirow{3}{*}{ For recognition (Selfish-01) } & \multirow{3}{*}{5} \\
\hline Sig. (2-tailed) & .019 & & \\
\hline $\mathrm{N}$ & 62 & & \\
\hline Pearson Correlation & $-.403^{*}$ & \multirow{3}{*}{$\begin{array}{l}\text { Have something to do with my free time } \\
\text { (Selfish- 02) }\end{array}$} & \multirow{3}{*}{6} \\
\hline Sig. (2-tailed) & .001 & & \\
\hline & 62 & & \\
\hline
\end{tabular}

Source: research data (2014).

Table 9 shows that the first four correlations are weak positive, belonging to the profile "altruism - 01, 02, 03, and 05." The fifth and sixth correlations are weak negative and moderate negative, respectively, belonging to the profile "selfish- 01 and $02 . "$

The first four correlations show that an increase in the respondents' level of education is accompanied by an increase in their intention to help others, make a difference in people's lives, bring hope to the less fortunate, and do something important, respectively. Correlations 5 and 6 show that a decline in volunteers' level of education accompanies an increasing likelihood of being motivated by a desire for recognition or to have something to do with their free time, respectively.

The data described above reinforce the findings by Silva and Villela (2008) that more highly educated individuals are more likely to display solidarity with fellow human beings and altruistic motives.

When the significant differences among groups at the moment of joining were analysed using ANOVA with Bonferroni test and Student's $t$ test, five differences among the groups were identified. Four of these differences were specifically linked to gender, marital state, whether a family member had ever performed volunteer work, and whether the individual had ever been invited by another person to perform volunteer work. The final difference was related to the different ministries.

The first difference among groups involved "gender," in which the only difference observed was among the relationships found for the variable "Social justice -2. ."

Table10-Differences among groups - "Gender"

\begin{tabular}{|c|c|c|c|}
\hline \multicolumn{4}{|c|}{ "Moment of joining" variable } \\
\hline Difference & g groups & & Motivation \\
\hline \multicolumn{2}{|c|}{ "Gender" } & $x$ & Social justice -2 \\
\hline Male & 5.33 & & "Reduce social injustice" \\
\hline Female & 7.08 & & \\
\hline
\end{tabular}


From the relationship shown in Table 10, it may be inferred that female volunteers at the foundation favour reducing social injustice; however, this issue was less important to male volunteers, as demonstrated by their lower means. Thus, it may be inferred that male volunteers' motives are not linked to a desire to "reduce social injustice." These results are similar to the findings by Souza et al. (2006).

With regard to the second difference related to "marital status," there were five among the relationships found for the variables of "Altruism - 3; Social justice - 2, 3, and 4; and Affiliation - 1."

Table 11-Difference among groups - "Marital status"

\begin{tabular}{|c|c|c|}
\hline \multicolumn{3}{|c|}{ "Moment of joining" variable } \\
\hline \multicolumn{2}{|l|}{ Difference among groups } & Motivation \\
\hline $\begin{array}{c}\text { "Marital status" } \\
\text { Single } 7.65\end{array}$ & \multirow[t]{2}{*}{$\mathrm{X}$} & \multirow[t]{2}{*}{$\begin{array}{c}\text { Altruism - } 3 \\
\text { "Bring hope to the less fortunate" }\end{array}$} \\
\hline Married & & \\
\hline "Marital status" & \multirow{3}{*}{$\mathrm{X}$} & \multirow{3}{*}{$\begin{array}{c}\text { Social justice }-2 \\
\text { "Reduce social injustice" }\end{array}$} \\
\hline Single 5.28 & & \\
\hline Married $\quad 7.13$ & & \\
\hline "Marital status" & \multirow{3}{*}{$\mathrm{X}$} & \multirow{3}{*}{$\begin{array}{c}\text { Social justice }-3 \\
\text { "Be a useful member of my community" }\end{array}$} \\
\hline Single 5.92 & & \\
\hline Married $\quad 7,66$ & & \\
\hline "Marital status" & \multirow{3}{*}{$\mathrm{X}$} & \multirow{3}{*}{$\begin{array}{c}\text { Social justice }-4 \\
\text { "Contribute to the betterment of society" }\end{array}$} \\
\hline Single 5.69 & & \\
\hline Married $\quad 7.58$ & & \\
\hline "Marital status" & \multirow{3}{*}{$\mathrm{X}$} & \multirow{3}{*}{$\begin{array}{c}\text { Affiliation }-1 \\
\text { "Meet people with similar interests" }\end{array}$} \\
\hline Single 5.58 & & \\
\hline Married & & \\
\hline
\end{tabular}

Source: Research data (2014).

Table 11 shows the highest means in the "married" status, especially in the "Altruism 3" motivation. The predominant motivation in the differences among groups is "Social justice," allowing one to infer that the foundation's volunteers are married, predominantly inclined towards social justice, and primarily motivated by altruism. These results are congruent with the findings by Figueiredo (2005).

In the third difference among groups at the moment of joining, referring to whether the volunteer was invited by someone to join, there were differences in relation to the "Social justice -2 " and "Learning -1 and 2" motivations.

Table 12-Difference among groups - "Were you invited by someone to join?"

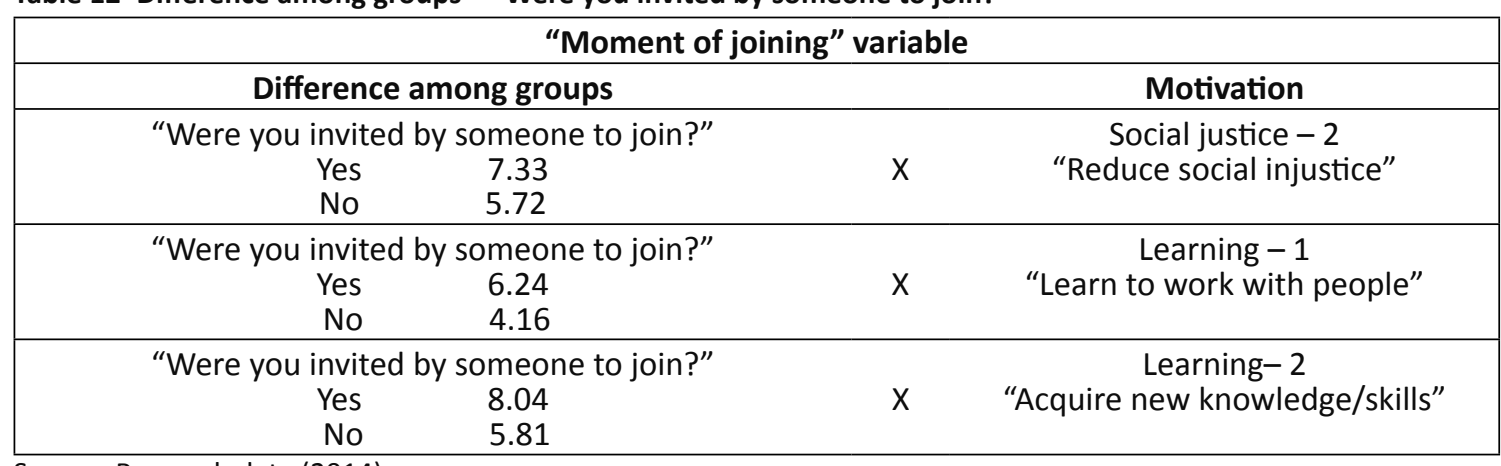

Source: Research data (2014). 
Considering the higher means found in Table 12, one can note that volunteers at the foundation studied were invited by someone to participate in volunteer activity, principally being motivated by a desire to "acquire new knowledge/skills." With this result, it is evident that the volunteers at the Cidade Viva Foundation are interested in learning something, as shown by the fact that their motivations are largely based on learning. Silva and Villela (2008) confirm these results, concluding that a friend's invitation is one of the primary reasons for engaging in volunteer work, citing social reasons and a desire for learning as being influential in this motivation.

\subsection{VOLUNTEERS' REASONS FOR QUITTING VOLUNTEER ACTIVITIES}

The "quitting" variable seeks to explain the reasons that lead volunteers who work at the Cidade Viva Foundation to quit their volunteer activity. The reasons for quitting were divided into three categories (lack of resources, religious reasons, and personal reasons)because they fit into each moment of "quitting." The following tables display the three factors and indicators of the moment of quitting with the results obtained in the survey.

Table 13 - Motivation for quitting volunteer activity

\begin{tabular}{cccc}
\hline Variable & Overall mean & Standard deviation & Coefficient of variation \\
Lack of resources & 1.42 & 1.52 & $106.77 \%$ \\
Religious reasons & 3.99 & 3.56 & $89.09 \%$ \\
Personal reasons & 2.20 & 2.39 & $108.68 \%$ \\
\hline
\end{tabular}

Source: Research data

Table 13 shows that the "lack of resources" variable obtained a low mean (1.42) and standard deviation (1.52), with a high coefficient of variation (106.77\%), indicating a very heterogeneous sample, with significant variation in the responses given. It may be inferred that, even under conditions of scarce resources, the foundation's volunteers would not quit their activity.

Similarly, religious reasons were not significant motivations for quitting volunteer work, given their low mean (3.99) and standard deviation (3.56). However, the data indicate a heterogeneous sample, with a high coefficient of variation (89.09\%). It is thus verified that, even if they were to lose or give up their religious beliefs such as faith in God and love for one's neighbour, the respondents would not quit their volunteer activity at the Cidade Viva Foundation. It is important to note that, in a certain sense, this is a significantly positive point for the foundation because the volunteers would ensure the continuity of the work and support for those who need them.

The profile results for the third and final variable, "personal reasons," showed a low mean value (2.20) and standard deviation (2.39), indicating a certain dispersion in the answers, in addition to a fairly high coefficient of variation, indicating the sample's heterogeneity. In this manner, these results resemble those obtained in the previous profiles, "lack of resources" and "religious reasons." Thus, it may be inferred that motives related to "lack of time," "living in a different neighbourhood," and "work load" would not be decisive factors causing volunteers to quit volunteering at the Cidade Viva Foundation.

The results presented here are consistent with the findings by Cavalcante et al. (2010) in that the variables of "lack of resources," "religious reasons," and "personal reasons" are not decisive factors causing volunteers to quit. In this sense, volunteers can be considered to have a high level of commitment to their volunteer work at the Cidade Viva Foundation because they demonstrate that there are no reasons that could interrupt their activity. Thus, the foundation and the individuals whom it helps can count on the continuity of their services. If this were not 
the case, the Cidade Viva Foundation would lose a great deal with the departure of a trained, skilled volunteer, resulting in higher costs to recruit, select, train, and incorporate a new volunteer into the organization's activities.

As with the "expectations" and "joining" phases, the findings reported here for the moment of quitting are all consistent with Cavalcante's model (2016), on which this study was based.

The only significant correlation found between the sociodemographic data and the "quitting" factor was for "income and government support," as shown in Table 14.

Table 14-Moment of quitting - Correlations between income and government support

\begin{tabular}{|c|c|c|c|}
\hline \multicolumn{2}{|c|}{$\begin{array}{l}\text { Sociodemographic profile } \\
\text { Income }\end{array}$} & Motivation & Correlation \\
\hline Pearson Correlation & $.282 *$ & \multirow{3}{*}{$\begin{array}{l}\text { I would leave the Cidade Viva Founda- } \\
\text { tion for lack of government support. }\end{array}$} & \multirow{3}{*}{1} \\
\hline Sig. (2-tailed) & .025 & & \\
\hline $\mathrm{N}$ & 63 & & \\
\hline
\end{tabular}

Source: Research data (2014).

A weak positive correlation was identified with regard to the "government support" motivation, allowing one to infer that, as a volunteer's income level rises, the volunteer is more likely to consider quitting his or her work at the foundation for lack of government support. Matsudo (2002) finds that volunteers enjoy a high level of income, which is related to these individuals' dissatisfaction, above all, with the lack of government support, and that this is the dimension with which they are least satisfied. Accordingly, one can infer that government aid to the institution may give rise to paternalist actions, which coincide with the basic principles of volunteerism.

Analysis of significant differences among volunteers at the time when they quit their work at the foundation identified differences among groups with respect to their responses on the sociodemographic section of the questionnaire. By means of the $t$ test, one significant difference was found with regard to the question of "Has a family member ever engaged in volunteer work?" and the variable of "Love for one's fellow human beings -1. ."

Table 15-Difference among groups - “Has a family member ever engaged in volunteer work?”

\begin{tabular}{ccc}
\multicolumn{3}{c}{ "Quitting” variable } \\
\hline Difference among groups & Motivation \\
\hline "Has a family member ever engaged in volunteer work?" & X & Love for one's fellow human beings - 1 \\
No & 2.62 & \\
\hline
\end{tabular}

Source: Research data (2014).

Based on the relationship described in the table above and taking into consideration the larger mean (4.62), it may be inferred that volunteers who have never had a family member engaged in volunteer work at the Cidade Viva Foundation would not consider love for one's fellow human beings as their primary motive for quitting work at the Foundation. On the other hand, the mean of 2.62 shows that volunteers who have a family member engaged in volunteer work believe, though less strongly, that they would not be moved to quit by lack of love for their fellow human beings. 


\section{FINAL CONSIDERATIONS}

The present study sought to analyse the motivations that lead volunteers and would-be volunteers to join and quit volunteer work at the Cidade Viva Foundation, located in the city of João Pessoa, Paraíba, Brazil. It seeks to make a useful contribution to the more efficient management of personnel in the organization under study, which can help reduce the turnover rate of volunteers through the development of better methods of recruiting and retaining would-be and current volunteers. The research was made possible by an assurance of access to the data, owing to the contact established between the researcher's advisor and the board of the foundation.

In terms of practical application, this study may permit managers to achieve a greater understanding of the diverse elements that compose the motivations that lead current and would-be volunteers to engage in this activity, in addition to their reasons for leaving. These results are important because these phases in the life cycle of a volunteer - applying for a volunteer position and the first year of volunteer work - are the most sensitive, given that, if the volunteer's attempts to satisfy his or her prior expectations are frustrated during the first year, then the volunteer will inevitably quit the NGO, exacerbating the primary problem of the high turnover rate among volunteers, which is the focus of the Third Sector Study Group's research. Considering that this study set out to discover volunteers' motivations for joining and quitting volunteer service at the Cidade Viva Foundation in the city of João Pessoa, Paraíba, Brazil, all of the responses have helped to reach the following conclusions: both in the phase of prior expectations and at the moment of joining, the most important motivations leading volunteers to participate in volunteer activity at the foundation were related to altruism, followed by a desire for social justice, learning, affiliation, and, finally, self-interest. These results corroborate the findings of other studies in this field. It was observed that volunteers' experience during their first year largely match their initial expectations, a point which speaks well of the institution's ability to sustain volunteers' expectations from the time when they begin through their first year of volunteer work.

The limitations of the study are related to the scarcity of publications on this issue that are specific to Brazil, which often restricts our understanding of the subject to the particular contexts of other countries. Another limitation involves the motivations presented here, which can change, depending on the intrinsic features of each organization. For this reason, the data found and discussed here cannot be generalized because other factors may be included and discussed in other studies on different organizations.

It is suggested that future studies examine men's participation in volunteer work because both this study and other works on the theme have shown the predominance of women in volunteer work. Next, an analysis of the role of older citizens in volunteer work is necessary because it would be interesting to observe and study this population's perspective on volunteer work, given that young people predominated in this study. Such studies could compare and contrast the motivations of the above-mentioned groups to the motivations of female and young volunteers with regard to prior expectations, joining, and possibly quitting, with an eye to observing the ways in which these segments may differ from the motivations of the group as a whole. 


\section{BIBLIOGRAPHY}

ALVES, M. A. Terceiro setor: as origens do conceito. ENANPAD - Encontro Anual da Anpad, v. 26, 2002.

AMORIM, H. K.; AMATUZZI, M. M. Vivência comunitária católica e crescimento pessoal. Psico, v. 42, n. 3, 2011.

ASSIS, L. B.; VIEGAS, G.; CKAGNAZAROFF, I. B. Gestão de Recursos Humanos no Terceiro Setor: um estudo descritivo das organizações de Belo Horizonte. GESTÃO.Org - Revista Eletrônica de Gestão Organizacional, v. 10, n. 2, 2012.

AZEVEDO, D.C. Voluntariado corporativo-motivações para o trabalho voluntário. XXVII Encontro Nacional de Engenharia de Produção. Foz do Iguaçu, Paraná, Brasil, 2007.

AZEVEDO, L. F. Gestão financeira de recursos no Terceiro Setor: proposta de modelo para gestão e prestação de contas das Organizações Não Governamentais. Trabalho de Conclusão de Curso, MBA, Departamento de Ciências Contábeis. Universidade Federal do Paraná, Curitiba, 2008.

BANG, H.; ROSS, S. D. Volunteer motivation and satisfaction. Journal of Venue and Event Management, v. 1, n. 1, p. 61-77, 2009.

BARELI, P.; DE SOUSA LIMA, A. J. F. A importância social no desenvolvimento do trabalho voluntário. Revista de Ciências Gerenciais, v. 14, n. 20, 2015.

BOZ, I.; PALAZ, S. Factors influencing the motivation of Turkey's community volunteers. Nonprofit and Voluntary Sector Quarterly, v. 36, n. 4, p. 643-661, 2007.

BRASIL. Presidência da República. Lei no 9.608 de 18 de fevereiro de 1998. Brasília, 1998. Disponível em: <http://www.planalto.gov.br/ccivil_03/leis/L9608.htm>.Acesso em: jan. 2013.

BURNS, D. J. et al. Motivations to volunteer: the role of altruism. International Review on Public and Nonprofit Marketing, v. 3, n. 2, p. 79-91, 2006.

CALDANA, A. C. F. et al. Sentidos das ações voluntárias: desafios e limites para a organização do trabalho. Psicologia \& Sociedade, v. 24, n. 1, p. 170-177, 2012. Disponível em: <http:// www.scielo.br/scielo.php?pid=S0102-71822012000100019\&script=sci_abstract\&t/n $g=p t>$. Acesso em: 10 jan. 2015.

CARTILHA DO TERCEIRO SETOR. Ordem dos Advogados do Brasil. São Paulo, 2005. Disponível em: <http://www.oabsp.org.br/comissoes2010/direito-terceiro-setor/cartilhas/REVISaO\%20 2011Cartilha_Revisao_2007_Final_Sem\%20destaque\%20de\%20alteracoes.pdf>. Acesso em: 04 jan. 2015.

CAVALCANTE, C. E. et al. Elementos do trabalho voluntário: motivos e expectativas na pastoral da criança de João Pessoa/PB. Revista Eletrônica de Ciência Administrativa, v. 10, n. 1, p. 98-110, 2011.

CAVALCANTE, C. E. Motivação de Voluntários: teoria e prática. Appris, 2016. 
CHAPMAN, G., WHITE P. As características singulares do ambiente do voluntariado. In:

As cinco linguagens de valorização pessoal no ambiente de trabalho. São Paulo: Mundo Cristão, 2012.

CIDADE VIVA. Conheça a Fundação. Disponível em: <http://cidadeviva. org/v2/igreja/conheca/ nossa-historia>. Acesso em 20 abr. 2014.

CLARY, E. G.; SNYDER, M.; RIDGE, R. Volunteers' motivations: A functional strategy for the recruitment, placement, and retention of volunteers. Nonprofit Management and Leadership, v. 2, n. 4, p. 333-350, 1992.

COELHO, S. de C. T. Terceiro Setor: um estudo comparativo entre Brasil e Estados Unidos. SENAC São Paulo, 2000.

COSTA, S. F. Gestão de pessoas em instituições do terceiro setor: uma reflexão necessária. Terra e Cultura, ano XVIII, no 35, p. 40-58, Londrina, julho/dezembro de 2002. Disponível em: < http://unifil.br/portal/images/pdf/documentos/revistas/revista-terra-cultura/terra-ecultura-35.pdf\#page=49>. Acesso em: 10 abr. 2014.

CVSP - CENTRO DE VOLUNTARIADO DE SÃO PAULO. Gerenciamento de Voluntário. São Paulo, 2001.

DIMAGGIO, P. J.; ANHEIER, H. K. The sociology of nonprofit organizations and sectors. Annual review of sociology, p. 137-159, 1990.

FERNANDES, R. C. Privado porém público: o terceiro setor na América Latina. Relume-Dumará, 1994.

FERREIRA, M. R.; PROENÇA, T.; PROENÇA, J. F. Motivations which influence volunteers' satisfaction. In: 10th International Conference of the International Society for Third Sector Research. 10th International Conference of the International Society for Third Sector Research, 2012.

FERREIRA, M. R.; PROENÇA, T.; PROENÇA, J. F. As motivações no trabalho voluntário. Revista Portuguesa e Brasileira de Gestão, v. 7, n. 3, p. 43-53, 2008.

FIGUEIREDO, N. C. M. Interfaces do trabalho voluntário na aposentadoria [dissertação]. Porto Alegre: Instituto de Psicologia, Universidade Federal do Rio Grande do Sul, 2005.

Disponível em: <http://www.lume.ufrgs.br/handle/10183/4448>. Acesso em: 04 jan. 2015.

GIL, A. C. Métodos e técnicas de pesquisa social. São Paulo: Atlas, 1999.

KUMMER, A. L. M.; OPICZH, A. M.; SANTOS, C. dos; SANTOS, L. R.; NORMANHA, M. A. Gestão de pessoas por organização do terceiro setor: avanço ou retrocesso nos serviços prestados? Cadernos da Escola de Negócios, Curitiba, v. 1, n. 8, p. 18-31, 2014.

MASCARENHAS, A. O; ZAMBALDI, F; VARELA. Motivação em programas de voluntariado empresarial: um estudo de caso. Revista Organizações em Contexto-online, v. 9, n. 17, p. 229-246, 2013.

MATSUDA, C. H. Estudo da satisfação dos voluntários engajados em entidades com área de atuação diversa, na cidade de Porto Alegre. Dissertação de Mestrado, Programa de Pós- 
Graduação em Administração. Universidade Federal do Rio Grande do Sul, Porto Alegre, 2002. Disponível em: < http://www.lume.ufrgs.br/handle/10183/3254>. Acesso em: 18 dez. 2014.

MARCONI, M. de A; LAKATOS, E. V. Fundamentos de metodologia científica. São Paulo: Atlas, 2010.

Técnicas de pesquisa. São Paulo: Atlas, 2011.

MCCURLEY, S.; LYNCH, R.; VESUVIO, D. A. Essential volunteer management. London: Directory of Social Change, 1998. Disponível em: <http://www.revistaespacios.com/ a12v33n09/12330914.html>. Acesso em: 24 dez. 2014.

MEDEIROS, J. K de O. Estudo da Motivação Voluntária na Fundação Cidade Viva. 2013. 72 f. Trabalho de Conclusão de Curso (Graduação em Administração) - Universidade Federal da Paraíba, João Pessoa, 2013.

MORAES, A. F. G. de; SILVA, A. G. C. da; CAVALCANTE, C. E. Sou feliz por ajudar os outros: motivação e felicidade no trabalho voluntário. In: VIII Encontro de Estudos Organizacionais da ANPAD, 2014. Disponível em: <http://www.anpad.org.br/diversos/trabalhos/EnEO/ eneo_2014/2014_EnEO136.pdf> Acesso em: 03 jan. 2015.

DE MOURA, L. R.; SOUZA, W. J de. Elementos do trabalho voluntário na pastoral da criança: Características e motivos. HOLOS, v. 3, p. 150-160, 2008.

OLIVEIRA, L. D.; PINTO, S.R. da R. A importância do trabalho voluntário no desenvolvimento de competências do estudante. Disponível em: < http://www.puc-rio.br/pibic/relatorio_ resumo2010/relatorios/ccs/adm/ADM-Lidiane\%20Duarte\%20Silva\%20de\%20Oliveira. pdf $>$. Acesso em: 26 dez. 2014.

RESS, A. P. P. de M.; MORAES, R. de O.; NAKANO, D. N. O uso da gestão de conhecimento como fator de moderação do impacto da alta rotatividade da equipe de TI no desempenho dos projetos. In: XXX ENCONTRO NACIONAL DE ENGENHARIA DE PRODUÇÃO, 2010, Anais eletrônico. São Paulo/SP. Disponível em: <http://www.abepro.org.br/biblioteca / enegep2010_TN_STO_120_783_16859.pdf>. Acesso em: 25 fev. 2013.

RIBEIRO, A. M. V. \& Luz, T. R. . O sentido do trabalho para trabalhadores de organizações não governamentais. In D. H. Helal, F. C. Garcia, \& L. C. Honório (Orgs.), Relações de poder e trabalho no Brasil contemporâneo (pp. 75-107). Curitiba: Juruá. 2010

RODRIGUES, M. C. P. Terceiro Setor: para que serve? Conjuntura Econômica, 41-45, São Paulo: FGV, 1997.

SALAMON, L. M. The Rise of the Nonprofit Sector. Foreign Affairs, vol. 74, no. 3, 1994.

SEVIGNANI, R. Terceiro setor: a participação do voluntariado na gestão do social em foz do Iguaçu. 59 f. Trabalho de Pós-Graduação (Gestão das Organizações), Universidade Estadual do Oeste do Paraná, Foz do Iguaçu, 2007.

SILVA, N. M. F. T.; VILLELA, L. E. Fatores motivacionais no trabalho voluntário: uma análise dialética à luz da sociedade pós-industrial, 2008. Disponível em: <http://old.angrad.org. br/_resources/_circuits/article/article_1106.pdf>. Acesso em: dez. 2014. 
SMITH, D. H. Four Sectors or five? Retaining the member-benefit Sector. Nonprofit and Voluntary Sector Quarterly. v. 20 n. 2, Summer 1991, p.137-50, 1991.

SOUR, R. H. Poder, cultura e ética nas organizações. Rio de Janeiro: Campus, 1999.

SOUZA, W. J. de; CARVALHO, V. D. de. Elementos do comportamento organizacional no trabalho voluntário: motivação na Pastoral da Criança à luz da teoria daexpectância. ENCONTRO ANUAL DA ASSOCIAÇÃO NACIONAL DE PROGRAMAS DE PÓS-GRADUAÇÃO EM ADMINISTRAÇÃO E PESQUISA - EnANPAD, v. 30, 2006.

TEODÓSIO, A. S. S. Organização do trabalho voluntário: estratégias para a gestão social no Brasil. In: ENCONTRO NACIONAL DE ENGENHARIA DE PRODUÇÃO, 2001. Anais eletrônico. Salvador/BA. Disponível em: < http://www.abepro.org.br/biblioteca/ENEGEP2001_ TR44_0550.pdf >. Acesso em: abr. 2014.

TRIGUEIRO, R. P. C. Percepções das relações entre trabalho remunerado e trabalho voluntário: um estudo com voluntários da Pastoral da Criança. Dissertação de Mestrado, Programa de Pós-graduação em Administração. Universidade Federal do Rio Grande do Norte, Natal, 2010.

\section{Contribution of authors}

\begin{tabular}{|c|c|c|c|c|}
\hline Contribution & [Author 1] & [Author 2] & [Author 3] & [Author 4] \\
\hline 1. Definition of research problem & $\mathrm{v}$ & $\mathrm{v}$ & & \\
\hline $\begin{array}{l}\text { 2. Development of hypotheses or research ques- } \\
\text { tions (empirical studies) }\end{array}$ & $\mathrm{v}$ & $\mathrm{v}$ & & \\
\hline $\begin{array}{l}\text { 3. Development of theoretical propositions } \\
\text { (theoretical work) }\end{array}$ & $\mathrm{v}$ & & & \\
\hline 4. Theoretical foundation / Literature review & $\mathrm{V}$ & $\mathrm{v}$ & & \\
\hline 5. Definition of methodological procedures & $\mathrm{V}$ & $\sqrt{ }$ & & \\
\hline 6. Data collection & & & $\mathrm{V}$ & $\mathrm{V}$ \\
\hline 7. Statistical analysis & $\mathrm{v}$ & & $\mathrm{V}$ & $\mathrm{v}$ \\
\hline 8. Analysis and interpretation of data & $\mathrm{v}$ & & $\mathrm{v}$ & $\mathrm{v}$ \\
\hline 9. Critical revision of the manuscript & $\mathrm{V}$ & $\mathrm{v}$ & $\mathrm{v}$ & $\mathrm{v}$ \\
\hline 10. Manuscript writing & $\mathrm{V}$ & & $\sqrt{ }$ & $\mathrm{V}$ \\
\hline 11. Other (please specify) & & & & \\
\hline
\end{tabular}

